\author{
Aleksander Kiklewicz (1) \\ Uniwersytet Warmińsko-Mazurski, Olsztyn \\ aleksander.kiklewicz@uwm.edu.pl \\ Sebastian Przybyszewski $\mathbb{0}$ \\ Uniwersytet Warmińsko-Mazurski, Olsztyn \\ sebastian.przybyszewski@uwm.edu.pl
}

\title{
ESTETYCZNE AKTY MOWY JAKO PRZEDMIOT PRAGMALINGWISTYKI: STATUS, FUNKCJE, FORMY.
}

\section{CZ. $I^{1}$}

Słowa klucze: pragmalingwistyka, akty mowy, estetyczne akty mowy, operatory interakcyjne, afektotwórcze akty pośrednie

Keywords: pragmalinguistics, speech acts, aesthetic speech acts, interactive operators, indirect affect-creating acts

\section{Wstęp}

Mimo że oddziaływanie estetyczne stanowi funkcję wyspecjalizowanych estetycznych aktów mowy (dalej - EAM; termin ten, różnie rozumiany, pojawia się w publikacjach: Hobohm 1991; Meister 2008; Kazankova 2010; Zeller 2010; Morgan 2017 i in.) - tekstów i wypowiedzi, a także funkcję komplementarną (np. w tekstach medialnych, zob. Lisowska-Magdziarz 2019: 53), aspekt estetyczny, ogólnie rzecz biorąc, znajduje się na uboczu problematyki pragmalingwistycznej ${ }^{2}$, zwłaszcza teorii aktów

1 Wkład współautorów jest równy i wynosi po 50\%.

2 W literaturze anglojęzycznej próby zastosowania pragmatyki do badań nad tekstami literackimi i wypowiedziami na temat wartości estetycznych podejmowano m.in. w publikacjach: Pratt 1977; Petrey 1990; Sell 1991; Mey 1999; Johansen 2002; Olsen, Pettersson 2005. 
mowy jako podstawowego obszaru badań funkcjonalno-komunikacyjnych nad językiem. Konstatacja ta dotyczy także pragmatyki funkcjonalnej, której zwolennicy badają teksty (w szczególności konwersacje) jako kategorie działalności językowej wyższego rzędu (zob. Norrick 2001), przy szczególnym uwzględnieniu kontekstów motywacyjnych (społecznych, poznawczych, sytuacyjnych), które nie były brane pod uwagę w klasycznej teorii aktów mowy Johna L. Austina. Dyskurs w badaniach tego typu jest rozpatrywany w ujęciu społeczno-krytycznym (w perspektywie rozwiązywania problemów społecznych), być może dlatego zagadnienia komunikacji estetycznej (w pewnym sensie „nieproblematycznej”) nie znajdują miejsca w publikacjach tego nurtu.

W klasyfikacji Wolfganga Heinemanna i Dietera Viehwegera (1991) funkcja estetyczna została pominięta $\mathrm{w}$ rejestrze czterech podstawowych funkcji tekstu: psychicznej, kontaktowej, informacyjnej i regulacyjnej. Niemieccy autorzy tłumaczą to tym, że aspekt estetyczny w komunikacji ma status drugorzędny. Z takim stwierdzeniem nie można się jednak zgodzić. Zwłaszcza w XX w. nasiliła się tendencja do przenikania się sztuki i życia - postępująca estetyzacja, której źródłem stała się panująca powszechnie, zwłaszcza za sprawą nowych mediów i technologii komputerowych, kultura designu (zob. Głutkowska-Polniak 2017: 13).

Estetyczne aspekty zachowań komunikacyjnych poruszane są $\mathrm{w}$ analizach integrujących osiągnięcia pragmatyki i stylistyki. Efektem integracji dwóch dyscyplin jest pragmastylistyka, będąca w gruncie rzeczy stylistyką, której warsztat badawczy poszerzony jest o narzędzia pragmatyki ${ }^{3}$. Przykładem utrzymanego w tym duchu opracowania jest książka Elisabeth Black (2006), w której autorka z pragmatycznego punktu widzenia interpretuje takie zjawiska, jak narracja, tropy stylistyczne czy symbolizm. Zakres zainteresowań pragmastylistyki krzyżuje się z tzw. pragmatyką literacką (Sell 1991; Mey 2001a; Pilkington 2010; Huang 2012: 175).

Należy zaznaczyć, że pragmatyka tekstu artystycznego ma charakter specyficzny: zarówno etap tworzenia tekstu, jak i etap jego percypowania realizują się poza rzeczywistą interakcją między autorem a czytelnikiem. Stopień zapośredniczenia tej interakcji ${ }^{4}$ jest w tym wypadku tak duży - pomiędzy autorem a czytelnikiem znajdują się instytucje wydawnicze, dystrybucyjne, opiniodawcze - iż za całkiem zasadne należy uznać stanowisko badaczy, którzy twierdzą, że literatura piękna stoi poza obrębem komunikacji społecznej (Sławiński 1974: 104; Sil'man 1977: 179; Stępnik 1988: 119; Admoni 1994: 120). „Rynek odbiorczy jest wtórną ojczyzną sztuki” czytamy w książce Marii A. Potockiej (2007: 102). Komunikacja w zakresie sztuki polega na czym innym, tj. na skoordynowanym i zasadniczo zapośredniczonym funkcjonowaniu osób i instytucji: artystów, wydawnictw, redakcji, recenzentów,

3

4

W Polsce jako jedna z pierwszych o stylistyce pragmatycznej pisała Krystyna Pisarkowa (1994). W przypadku literatury artystycznej występuje, według określenia Teresy Dobrzyńskiej (2001: 47), „odbiorca wirtualny”. W zasadzie nadawca - z punktu widzenia sytuacji odbioru - także ma charakter wirtualny. 
dystrybutorów, sprzedawców, bibliotek, archiwów, krytyków literackich, czytającej publiczności. Pod tym względem do opisu komunikacji estetycznej nadają się teorie powstałe w nurcie konstruktywizmu społecznego.

Autorzy prezentowanego artykułu wychodzą z założenia, że intencja estetyczna (jako zamiar wywołania wrażenia estetycznego u adresata) stanowi jedną $z$ wielu innych intencji (poinformowania, pozyskania informacji, zachęcania, zniechęcania, pozdrowienia itp.), dlatego zachowania mowne mające wywołać przeżycie estetyczne mogą być badane przy zastosowaniu standardowych narzędzi pragmalingwistyki, w szczególności teorii aktów mowy. Oczywiście na tle innych aktów zachowania te wyróżniają się pewnymi cechami, które zostaną zaprezentowane w kolejnych rozdziałach.

\section{Status i funkcja pragmatyczna EAM}

Fenomen sztuki i działalności estetycznej zawiera w sobie pewną sprzeczność: mimo że wyodrębnienie obiektów o nacechowaniu estetycznym zwykle nie sprawia trudności, nie istnieje jedyna, uniwersalna podstawa zdefiniowania sztuki z semiotycznego punktu widzenia (więcej o tym zob.: Kiklewicz 2007: 46 i n.). Przekonuje o tym historia sztuki, w której występują paradygmaty odwołujące się do różnych wyznaczników estetyczności - takich jak pierwszeństwo reguł formalnych i dostosowanie do nich treści semantycznej w sztuce klasycyzmu, pierwszeństwo informacji semantycznej w sztuce realizmu, nadmiar uporządkowania i semantyzacja relacji wewnątrztekstowych w sztuce modernizmu, pierwszeństwo kontekstu i hipertekstowość $\mathrm{w}$ sztuce postmodernizmu ${ }^{5}$. Istnieje poza tym wiele form realizacji funkcji estetycznej w tym samym czasie i w tym samym systemie kulturowym ${ }^{6}$.

Wynika z tego, że zdefiniowanie sztuki czy też stylu artystycznego w oparciu o kryteria semiotyczne (formalne czy strukturalne) jest prawie że niemożliwe - pozostaje kryterium uznaniowe, czyli pragmatyczne: status obiektów estetycznych jest kwestią uznania ${ }^{7}$. Podobna sytuacja występuje w zakresie stylu dziennikarskiego: „O prasowości wypowiedzi rozstrzyga jej... prasowość”, tzn. typowe dla dziennikarstwa gatunki (Bauer 2000: 146).

Zastosowanie specjalnych zabiegów językowych (tzw. figur retorycznych) często wydaje się wystarczające, żeby wyodrębnić EAM na tle innych typów wypowiedzi,

5 Zasadniczo odmienny stosunek do zasad estetyki w sztuce tradycyjnej i nowoczesnej jest jednym z głównych wątków monografii Marii Potockiej (2007: 21 i n.).

6 Nina B. Mečkovskaâ (1996: 33) twierdzi, że język artystyczny zawiera elementy wszystkich stylów funkcjonalnych.

7 „[...] Za sztukę uważać to, co sztuką zostanie uznane” (Potocka 2007: 108). Mary L. Pratt (1977) pisze, że gwarantem stosownego odczytania tekstu artystycznego jest żywione przez czytelnika założenie literackości (ang. assumption of literariness). 
zwłaszcza aktów reprezentacyjnych. Stąd na przykład Andrew Morgan (2017: 96 i n.) posługuje się opozycją: aesthetic vs. ordinary assertion. Rzeczywiście wiele EAM przyjmuje formę typową dla aktów reprezentacyjnych (informacyjnych), jednak gramatyczna struktura wypowiedzi nie decyduje o funkcji pragmatycznej. W wypadku EAM intencja nadawcy nie dotyczy przekazywania informacji o ładnych rzeczach (czyli, jak to określa wspomniany wyżej A. Morgan, asercji estetycznych ${ }^{8}$ ) ani wyrażania stanów afektywnych nadawcy. Za EAM należy uznać kategorię aktów sprawczych, które - w odróżnieniu od dyrektywów behawioralnych - mają charakter pobudzający (stymulujący, afektotwórczy) ${ }^{9}$. W obrębie tej kategorii (która łączy akty przestraszenia, rozbawienia, pocieszenia, rozzłoszczenia itp.) EAM wyróżniają się wywoływaną u adresata reakcją - jest to przeżycie estetyczne ${ }^{10}$, o którym M.A. Potocka (2007: 163 i n.) pisze jako o „strategicznym pojęciu estetyki tradycyjnej”. Fizyczne wytworzenie tekstu, który w założeniu nadawcy ma walory estetyczne, stanowi lokucyjną część aktu mowy, a intencja wywołania u adresata przeżycia estetycznego przekłada się na moc illokucyjną wypowiedzi. Sam fakt takiego przeżycia stanowi efekt perlokucyjny, który - choć wywołany przez nadawcę - w odróżnieniu od lokucji i illokucji w pełni od niego nie zależy.

\subsection{EAM: bezpośrednie i pośrednie formy realizacji}

Illokucja afektotwórcza, jako plan treści EAM, warunkuje możliwości ich realizacji. W odróżnieniu od dyrektywów behawioralnych (prośby, polecenia, rady, propozycji itp.) mamy tu do czynienia z próbą wywołania u odbiorcy doświadczenia

8 Asercje na temat wartości estetycznej obiektu (To jest piękne; Pięknie to napisałaś; To, co powiedzieliście, było przecudne) to sądy dotyczące zastosowania normy estetycznej do określonych obiektów i stanów rzeczy. Tego rodzaju asercje podobne są do asercji moralnych/etycznych, funkcjonalnych, epistemicznych.

9 Tekst powieści nie przypomina typowego dyrektywu typu Daj mi ten list, ale na sprawczy charakter EAM wskazuje możliwość ich realizacji w formie typowej dla dyrektywów: Poczuj piękno tego miasta! (zob. 2.2.). Dyrektywy/apelatywy behawioralne (działaniotwórcze) i stanowe (stanotwórcze) istotnie różnią się tym, że w pierwszym przypadku nadawca bezpośrednio wpływa na ośrodek refleksji adresata (refleksji interpersonalnej), a w drugim przypadku (przy oddziaływaniu na emocje czy przekonania) musi się liczyć z tym, że reprezentacje mentalne mają charakter autopojetyczny, zgodnie z biologią poznania w wersji Humberta R. Maturany i Francisca J. Vareli (1987). Dlatego Hans-Christoph Hobohm (1991: 548) konstatuje, że użycie języka w komunikacji artystycznej ma charakter nieinstrumentalny.

10 W odniesieniu do literatury pięknej Valerij Z. Dem'ânkov (2016: 31) pisze o „uniesieniu czytelnika" (ros. воспарение читателя). Należy też zaznaczyć, że przeżycie estetyczne jako cel czynności językowej nie jest równoważne z doznawaniem piękna: nadawca może dążyć do wywołania $\mathrm{u}$ adresata także uczucia brzydoty, choć na mocy komunikacyjnej reguły uczciwości czyni to zwykle w celu realizacji innej intencji (np. zniechęcenia). 
estetycznego ${ }^{11}$. Specyfika tej sytuacji polega na tym, że człowiek nie jest $\mathrm{w}$ stanie całkowicie kontrolować swoich uczuć, takich jak radość, smutek, trwoga, niepokój itp. (przysłowie mówi: „Serce nie sługa”), a tym bardziej uczuć innych ludzi. Tym się tłumaczy fakt, że słownie zamanifestowane apele mające wpływać na (zwłaszcza negatywne) uczucia adresata z pragmatycznego punktu widzenia przeważnie są niefortunne, jak w poniższych, możliwych do wykreowania wyrażeniach:
(1) $\quad{ }^{*}$ Miej trwogę...
(2) ${ }^{\star}$ Nudźcie się...
(3) ${ }^{\star}$ Niech pan tęskni...
(4) ${ }^{\star}$ Przestrasz się... ${ }^{12}$

W wypadku aktów afektotwórczych (w tym estetycznych) nie jest możliwa racjonalnie uzgodniona, reglamentowana kooperacja interlokutorów, zobowiązanie adresata do przeżycia estetycznego, na co wskazuje między innymi Theodor W. Adorno: „To, co artysta chce powiedzieć, mówi wyłącznie przez ukształtowanie [elementów dzieła - A.K., S.P.], a nie poprzez podawanie o nim informacji” (1994: 274; zob. też: Hobohm 1991: 548). Właśnie tym się tłumaczy przeważnie pośredni charakter takich aktów, tzn. brak wyspecjalizowanego operatora interakcyjnego. Użycie takiego operatora wydaje się sprzeczne z założeniem skuteczności zabiegu komunikacyjnego:

(5) ? Zachęcam, żebyś odczuwał przyjemność estetyczną.

(6) ? Sprawiam, że poczujesz w sobie coś pięknego.

? Sprawię za moment, że poczujesz w sobie coś pięknego.

(7) ? Wywołuję u pani przeżycie wzniosłości.

? To, co za chwilę powiem, wywoła u pani przeżycie wzniosłości.

11 Z perspektywy psychologii estetyki „doświadczenie estetyczne można zdefiniować jako ogólny proces związany z kognitywną i afektywną reakcją danej osoby na obiekt należący do szczególnej klasy przedmiotów zwanej sztuką" (Mastandrea 2015: 500).

12 Owszem, istnieją przykłady użycia czasowników performatywnych realizujących intencję ingerencji nadawcy w sferę uczuć adresata: Ciesz się, że jesteś zdrowy; Uspokój się!; Bądź wesoły!; Radujmy się, weselmy się, śpiewajmy razem!; Rozczaruję cię: nie gram. Są to jednak formy czasowników trybu rozkazującego, które raczej zawierają apelacje do rozsądku adresata. W pierwszym zdaniu nadawca przekonuje adresata, że ten musi się cieszyć, gdyż jest zdrowy; w drugim zdaniu zachęca do tego, żeby adresat opanował swoje emocje, lub powstrzymuje go przed niepożądanym zachowaniem. W trzecim zdaniu adresat jest zachęcany do bycia wesołym - nie jest to jednak bezpośrednie powodowanie wesołości (jak np. w seansie hipnozy). Czwarte zdanie pochodzi z dyskursu religijnego i stanowi zachętę do wspólnego doznawania radości dzięki uświadamianiu sobie obecności Ducha Świętego. W piątym zdaniu czasownik występuje w formie czasu przyszłego i stanowi formę zapowiedzi. 
Jak funkcjonuje mechanizm oddziaływania pośredniego, można pokazać na przykładzie reklamy. Główna funkcja reklamy ma charakter perswazyjny, element estetyczny występuje zaś po to, aby wzmocnić perswazję. Autorzy przytoczonej reklamy piwa marki Żywiec (zob. rys. 1) zastosowali językowe środki upiększenia przekazu, oparte na właściwościach leksykalno-fonetycznych języka, zwłaszcza na zjawisku paronomazji. Obydwa slogany:

(8) Żywiec. Chce się Ż.

(9) Żona bez Ż to tylko ona.

są oparte na skojarzeniach fonetyczno-graficznych wyrazów: Żywiec - żona, $\dot{Z} y w i e c-\dot{z} y c ́$, wobec czego powstaje dwuznaczność:

(10) Chce się Ż

= Chce się żyć

= Chce się napić piwa Żywiec.
Rys. 1. Gra językowa w reklamie marki piwa Żywiec

Taka dwuznaczność nawiązuje do stylu artystycznego, co z kolei sprzyja powstaniu efektu aureoli, tzn. pozytywnego skojarzenia związanego z reklamowanym obiektem.

Pośredni charakter wielu EAM nie może być argumentem przeciwko uznaniu ich za odrębną kategorię pragmatyczną, jako że poza nielicznymi aktami mowy, które wymagają użycia czasownika performatywnego (np. chrzcić), większość jest możliwa do zrealizowania bez leksykalnego wykładnika illokucji, a liczne są również akty mowy, którym takiego wykładnika przypisać się nie da (por. Mey 2001b: 106).

EAM z reguły występują jako integralna część aktów synkretycznych (zob. 2.2.), tzn. takich, które jednocześnie realizują dwie funkcjonalnie powiązane ze sobą illokucje. W odniesieniu do wyrażenia (10) można to pokazać tak:

$$
\begin{aligned}
& \text { lokucja_1 }>\text { illokucja_1 [informowanie] } \\
& \text { lokucja_1 }>\text { illokucja_2 [stymulacja estetyczna] }
\end{aligned}
$$

Pod względem pośredniego sposobu realizacji EAM przypominają akty mowy o charakterze awersyjnym. Zeno Vendler (1976) pisał, że w przypadku twierdzeń nadawca dąży do tego, żeby adresat o czymś się dowiedział lub w coś uwierzył. Wyrażenie

(11) ${ }^{\star B e z p o d s t a w n i e ~ t w i e r d z e ̨, ~ z ̇ e . . . ~(p) . ~}$ 
jest sprzeczne z tym celem: przysłówek deprecjonuje wartość przekazywanej informacji i tym samym - w założeniu - zniechęca adresata do jej zaakceptowania. Z. Vendler określa podobne wyrażenia jako pseudoperformatywne, a ich użycie uważa za równoważne z "samobójstwem illokucyjnym” (ibid.: 144). Przysłówki bezpodstawnie, gołosłownie, bezmyślnie itp. uniemożliwiają - za sprawą „konfliktu intencji”, jak zaznacza Carl Ginet (1979: 261) - powodzenie aktu poinformowania. Tego rodzaju dysfunkcyjność wiąże się z używaniem czasowników nazywających czynności mowne sprzeczne z zasadami komunikacji kooperacyjnej, zwłaszcza z wymogami prawdziwości i uczciwości wobec adresata, np. angielskie czasowniki allege 'twierdzić bezpodstawnie', insinuate 'insynuować', brag 'chwalić się i in. ${ }^{13}$

Należy zaznaczyć, że istnieją okoliczności, w których zakaz używania wypowiedzi quasi-performatywnych nie obowiązuje. Po pierwsze, są to akty komplementarne, występujące w tle głównej illokucji, informujące o przesłankach, warunkach, przyczynach i innych okolicznościach stanów rzeczy będących przedmiotem głównej illokucji. Oto kilka przykładów ${ }^{14}$ :

(12) Pochlebiam ci, bo chcę, żebyśmy byli razem.

(13) Mimo że mówię to gołosłownie, jestem przekonana, że to prawda.

(14) Jeśli teraz mówię nieprawdę, to tylko dlatego, że mam takie źródła, a nie inne.

(15) Lecz choć się chwalę, kunszt ten jest mi naprawdę znany.

Po drugie, na quasi-performatywny charakter wypowiedzi wpływa także sfera interakcji: w dyskursach oficjalnych obecność wykładników czynności awersyjnych jest bardziej naturalna, a w pewnych sytuacjach, np. w debatach publicznych, wręcz wymagana:

(16) Krytykuję Pana za to, że nie podejmuje pan pewnych działań.

(17) Zarzucam Panu, że zakłada Pan koszty finansowe jedynie w czasie budowy.

(18) Potęiam Pana wypowiedzi na tym portalu.

Wspomniane wyżej okoliczności są ważne także w zakresie funkcjonowania EAM. Mimo że stosowanie wyspecjalizowanych operatorów czynności afektotwórczych w komunikacji codziennej nie jest praktykowane, to jednak w sytuacjach o charakterze formalnym lub instytucjonalnym występują pewne formy, za pomocą których intencja estetyczna nadawcy jest manifestowana - chodzi o nazwy gatunków w literaturze pięknej: powieść, poemat, komedia, ballada itd.

13 Michail Û. Fedosûk (1997: 74 i n.) uważa, że pochlebianie jako akt mowy nie ma wyspecjalizowanych wykładników formalnych i w mowie "podszywa się pod wypowiedzi innego rodzaju” (ros. „маскируется под высказывания других типов”).

14 Na ten rodzaj nieperformatywnego użycia czasowników performatywnych zwracał już uwagę John Austin (1993: 605 i n.). 
Wykorzystanie czasownikowych operatorów afektotwórczych możliwe jest pod warunkiem odwołania się do zawartej w komunikacie lub znajdującej się w otoczeniu aktu mowy informacji semantycznej, wywołującej u adresata skojarzenia z kategorią piękna. Za przykład może posłużyć slogan reklamowy (przeważnie występujący w reklamach kosmetyków):

(19) pol. Poczuj piękno!

ang. Feel beauty!

ros. Почувствуй красоту!

W tym przypadku nadawca raczej przekonuje adresata, że pewien stan rzeczy zasługuje na kontemplację estetyczną, niż bezpośrednio ją powoduje. Funkcję sprawczą realizuje tu czasownik w formie imperatywnej, ale jest to możliwe dzięki jego odniesieniu do środowiska wizualnego, w którym znajduje się slogan reklamowy ${ }^{15}$, jako obiektu kontemplacji adresata. Bodziec takiej kontemplacji może być zawarty także w treści elementów werbalnych wypowiedzenia, por.:

(20) Poczuj piękno tego miasta, gdy po zachodzie słońca światła zabytkowych budynków odbijają się od północnego błękitu Łaby.

O ile w przypadku dyrektywów reakcja adresata jest programowana w treści operatora interakcyjnego (Proszę, żebyś...), o tyle w przypadku EAM temu celowi służy cała zawartość wypowiedzenia, a poza tym jego forma językowa, kontekst i sposób przekazu (więcej o tym zob. w części II).

Należy zaznaczyć, że status wspomnianych wyżej nazw gatunków artystycznych jako operatorów interakcyjnych jest względny. Zwolennicy socjolingwistyki interakcyjnej (zob. Gumperz 1992) traktują takie operatory gatunkowe jako sygnały kontekstualizacyjne ${ }^{16}$, a Teresa Dobrzyńska pisze, że „ich rola jest tym istotniejsza, im swobodniej i mniej stereotypowo powiązane są sekwencje znaków w tekście" (2001: 52). Nazwy gatunków funkcjonują jednak inaczej niż czasowniki performatywne, a także ich odpowiedniki rzeczownikowe (np. prośba < prosić): są to określenia typu tekstu poprzez nawiązanie do wzorca gatunkowego. Tak więc wyraz powieść na stronie tytułowej książki nie jest równoważny z wyrażeniem performatywnym

(21) Opowiadam ci powieść o tym, że... ${ }^{17}$

15 Zob. jako przykład: https://youtu.be/4U2VsCTcY5Q.

16 W polskim tłumaczeniu Pragmatyki Stephena C. Levinsona (2010) oddano oryginalne contextualization cues jako wskazówki kontekstualizacji.

17 Choć wyraz powieść historycznie pochodzi od czasownika powiadać. 
Poprzez nawiązanie do określonego wzorca autor sugeruje pewien typ interpretacji tekstu. U podstaw takiej interpretacji leży wspólna dla uczestników dyskursu wiedza o gatunkach sztuki, między innymi wiedza o tradycji literackiej (zob. Sławiński 1974: $149^{18}$ ). Według M.A. Potockiej (2007: 165) przeżycie estetyczne może być związane $\mathrm{z}$ „rozpoznaniem znanych już skądinąd rozwiązań formalnych” (czyli typu strukturyzacji tekstu).

Rzeczownikowe formy manifestacji intencji pragmatycznej nadawcy: prośba, rada, propozycja, obietnica itp. wskazują na realizowaną przez nadawcę czynność i przewidują informację o zakresie odniesienia, por.:

(22) Oto moja prośba: żeby ktoś mnie poinstruował, jak się z tym obchodzić.

Inaczej funkcjonują nazwy gatunkowe: nie wskazują na czynność nadawcy, który tak naprawdę już swoje uczynił, tworząc dzieło artystyczne, lecz - jak zaznaczyliśmy - informują o określonej konwencji gatunkowej i odpowiednim sposobie interpretacji tekstu (zob. Traugott 1973: 20; Pratt 1977: 86). W podobny sposób funkcjonują modyfikatory estetyczne w konstrukcjach z imiesłowem, komplementarne w stosunku do głównej asercji:

(23) To, że posiedzenie się odbędzie, mówiąc elegancko, nie jest przesądzone.

(24) Grzaniec to, ładnie mówiąc, Poncz Bożonarodzeniowy czy też Punsch.

(25) Trzeba - mówiąc metaforycznie - oczyścić swoją smartfonową szafę.

(26) Przychodzimy na ten świat - mówiąc słowami poety - „ze smugą chwały”.

(27) Każda twarz, wyrażając się artystycznie, ma dwie strony i liczne wyglądy.

(28) Droga, poetycko mówiąc, wiedzie przez gwiazdy.

Wyrażenia metatekstowe mówiąc elegancko, mówiąc metaforycznie, ładnie mówiąc itp. mają charakter komplementarny, a ich funkcja polega na prezentacji mowy - nawiązaniu do konwencji estetycznej.

\subsection{EAM jako akty powiązane}

W przytoczonych powyżej wypowiedziach mamy do czynienia z realizacją dwóch intencji pragmatycznych, z których intencja estetyczna jest na drugim planie. Tak funkcjonuje wiele, a być może większość EAM, zwłaszcza poza obrębem sztuki.

18 V.Z. Dem'ânkov (2016: 31) podkreśla, że interpretacja dzieła artystycznego w dużym stopniu opiera się na kompetencji poznawczej czytelnika: „kreatywność to forma racjonalności, a nie tylko poloty fantazji” (ros. „креативность - это форма рассудочности, а не простые брызги фантазии"). 
Ogólnie rzecz ujmując, można wyodrębnić trzy rodzaje skonfigurowania EAM z kontekstem. Pierwszy typ to autonomiczne użycie EAM, gdy w obrębie sytuacji komunikacyjnej nie występują inne, powiązane akty mowy. W sytuacjach tego rodzaju informacja semantyczna jest zminimalizowana. Za przykład może posłużyć poezja absurdu lub inne gatunki (np. haiku) zaliczane do „czystej” sztuki, nieobarczonej tendencyjnością literatury realistycznej. Oto fragment wiersza niemieckiego poety Hugona Balla pt. Totenklage, który składa się z niezrozumiałych quasi-wyrazów:

(29) omula
take
biti
solunkola
tabla tokta ta kabla
taka tak
tabubu
m'balam
tak tru-ü
wo-um
biba bimbel

Drugi typ funkcjonowania EAM obserwujemy w sytuacjach, gdy oddziaływanie estetyczne ma charakter komplementarny, powiązane jest $z$ aktem głównym - informacyjnym, dyrektywnym bądź etykietalnym ${ }^{19}$. W tym wypadku illokucja estetyczna bazuje na lokucji, tzn. na semantycznych lub formalnych charakterystykach wypowiedzi, a także na jej otoczeniu lub sposobach przekazu - te wszystkie narzędzia oddziaływania estetycznego zostaną opisane w II części artykułu. Za przykład użycia EAM w układzie symultanicznym może posłużyć post na Facebooku ${ }^{20}$ :

(30) W przyjaźni jest jak w bajce. Kolorowo i wesoło. Słowa czasami są zbędne, serce wychwytuje chwile... Jest zaskakująca, jak letnia ulewa, jak liść jesienny, co spadł z drzewa.

Z jednej strony illokucja główna ma charakter reprezentacyjny: autor (a dokładniej - autorka) tekstu informuje o swoim zdaniu na temat przyjaźni. $Z$ drugiej strony sposób informowania różni się od tego, który występuje w komunikacji codziennej: w tekście użyto poetyzmów leksykalnych, a także charakterystycznych dla literatury pięknej konstrukcji porównawczych: jak w bajce, jak liść jesienny.

19 Aleksej A. Leont'ev (1968: 101) traktował informowanie i nakłanianie jako podstawowe czynności językowe, a czynności estetyczne (wraz z ekspresywnymi, fatycznymi i metajęzykowymi) jako opcjonalne.

20 https://www.facebook.com/groups/1889621664440861/permalink/3648857735183903. 
W komunikacji promocyjnej EAM są używane w kontekście illokucji dyrektywnej, co obserwowaliśmy na przykładzie reklamy piwa marki Żywiec (zob. 2.1.). Informacja estetyczna stanowi tu narzędzie perswazji: nadawca skłania adresata do przeżycia estetycznego i jednocześnie sugeruje, że skoro oferta wywołuje u adresata przyjemność estetyczną, zasługuje ona na jego akceptację jako całość. Zjawisko to można opisać poprzez odwołanie się do znanego w psychologii społecznej efektu kotwiczenia: „komunikat nadany w pierwszej kolejności będzie odznaczał się nieproporcjonalnie większą siłą oddziaływania w stosunku do pozostałych informacji zawartych w komunikacie" (Wanat 2006: 206). W tekstach reklamowych (i innych perswazyjnych) często wykorzystywane są elementy stylu artystycznego, np. metafory. Jest to forma stosowania swoistej kotwicy, tzn. uaktywnienie określonego ośrodka pobudzenia psychicznego adresata, który będzie miał wpływ na inne ośrodki, zwłaszcza na interpretację innych cech obiektu, i tym samym będzie sprzyjał perswazji (więcej o tym zob.: Kiklewicz 2020: 324 i n.). Na przykład slogan reklamowy kosmetyków do włosów Gliss Kur brzmi:

(31) Rozpieszcza włosy i zmysły.

Autor reklamy posługuje się metaforą, licząc na to, że za jej pomocą uda mu się przedstawić produkt w sposób bardziej atrakcyjny i w konsekwencji stanie się on bardziej pożądany przez potencjalnego konsumenta. Tu i w podobnych sytuacjach mamy do czynienia ze zjawiskiem, gdy perlokucja (pobudzenie estetyczne adresata) jest wykorzystywana w celu uzasadnienia dyrektywnego aktu mowy: 'Za sprawą tego, że X wywołuje u Y-a uczucie przyjemności estetycznej, X sprawia, że Y uważa, że przedmiot, o którym mówi X, jest bardzo dobry, i Y będzie chciał w związku z tym uczynić to, co sugeruje X'.

Trzeci typ użycia EAM polega na tym, że illokucja informująca realizuje się w tle illokucji afektotwórczej (Hobohm 1991: 548). Informowanie jest w większym stopniu charakterystyczne dla tekstów prozy, a także tekstów wieloformatowych (takich np. jak poemat) niż dla poezji lirycznej. W rosyjskim kręgu kulturowym szeroko znane jest określenie Wissariona G. Bielińskiego „encyklopedia życia rosyjskiego”, którym obdarzył on powieść poetycką Eugeniusz Oniegin Aleksandra Puszkina.

\section{Literatura}

Admoni V.G., 1994, Sistema form rečevogo vyskazyvaniâ, Sankt-Peterburg. Adorno T.W., 1994, Teoria estetyczna, Warszawa. Austin J.L., 1993, Mówienie i poznawanie. Rozprawy i wykłady filozoficzne, Warszawa. Bauer Z., 2000, Gatunki dziennikarskie, [w:] idem, E. Chudziński (red.), Dziennikarstwo $i$ świat mediów, wyd. 2 zm. i rozsz., Kraków, s. 143-173. 
Black E., 2006, Pragmatic Stylistics, Edinburgh.

Dem'Ânkov V.Z., 2016, Âzykovaâ kreativnost'v hudožestvennom tvorčestve, „Trudy Instituta russkogo âzyka im. V.V. Vinogradova" 7 (4), s. 29-35.

DobrzyŃska T., 2001, Od niespójności do (super)koherencji. Rola metatekstu w utworze literackim, [w:] A. Pajdzińska, R. Tokarski (red.), Semantyka tekstu artystycznego, Lublin, s. $47-57$.

Fedosûk M.Û., 1997, Issledovanie sredstv rečevogo vozdejstviâ i teoriâ žanrov rečy, [w:] V.E. Gol'din (red.), Žanry reči, Saratov, s. 66-88.

Ginet C., 1979, Performativity, „Linguistics and Philosophy” 3, s. 245-265, https://doi. org/10.1007/BFo0126512.

GŁutKowska-Polniak A., 2017, Dizajn w kontekście estetyki. Jego początki, przeobrażenia i konotacje, „Prace Naukowe Uniwersytetu Śląskiego w Katowicach”, nr 3588, Katowice.

Gumperz J.J., 1992, Contextualization and Understanding, [w:] A. Duranti, Ch. Goodwin (red.), Rethinking Context. Language as an Interactive Phenomenon, Cambridge, S. 229-252.

Heinemann W., Viehweger D., 1991, Textlinguistik. Eine Einführung, Tübingen, https:// doi.org/10.1515/9783111376387.

Новонм H.-Ch., 1991, Der ästhetische Text als Depositum von Weisheit, [w:] A. Assman (red.), Weisheit. Archäologie der literarischen Kommunikation III, München, s. 547-554.

Huang Y., 2012, The Oxford Dictionary of Pragmatics, Oxford, https://doi.org/10.1093/ oxfordhb/9780199697960.001.00o1.

Johansen J.D., 2002, Literary Discourse: A Semiotic-Pragmatic Approach to Literature, Toronto, https://doi.org/10.3138/9781442676725.

Kazankova E.A., 2010, Korrelâcii meždu sostavom personažej i illokutivnoj strukturoj ih kommunikativnyh partij (na materiale povestej G. Serbakovoj i L. Ulickoj), „Učenye zapiski UO VGU im. P.M. Mašerova" 10, s. 19-26.

KIKLEWICZ A., 2007, Zrozumieć język. Szkice z filozofii języka, semantyki, lingwistyki komunikacyjnej, Łask.

KiklewiCz A., 2020, Fenomeny komunikacji (normy $i$ dewiacje w zachowaniach językowych), Olsztyn.

LEONT'Ev A.A., 1968, Obŝestvennye funkcii âzyka i ego funkcional'nye èkvivalenty, [w:] F.P. Filin (red.), Âzyk i obŝestvo, Moskva, s. 99-110.

Levinson S.C., 2010, Pragmatyka, Warszawa.

Lisowska-Magdziarz M., 2019, Znaki na uwięzi. Od semiologii do semiotyki mediów, Kraków, https://doi.org/10.12797/9788381381178.

Mastandrea S., 2015, How Emotions Shape Aesthetic Experiences, [w:] P.P.L. Tinio, J.K. Smith (red.), The Cambridge Handbook of the Psychology of Aesthetics and the Arts, Cambridge, s. 500-518, https://doi.org/10.1017/CBO9781139207058.024.

Maturana H.R., Varela F.J., 1987, The Tree of Knowledge. The Biological Roots of Human Understanding, Boston.

Meister J.C., 2008, Computing Action. A Narratological Approach, Berlin - New York.

MečKovskaÂ N.B., 1996, Social'naâ lingvistika, Minsk.

Mey J.L., 1999, When Voices Clash. A Study in Literary Pragmatics, Berlin, https:/doi.org/ $10.1515 / 9783110801415$. 
Mey J.L., 2001a, Literary Pragmatics, [w:] D. Schiffrin, D. Tannen, H.E. Hamilton (red.), The Handbook of Discourse Analysis, London, s. 787-797, https://doi.org/10.1002/978047 0753460.ch41.

Mey J.L. 2001b, Pragmatics: An Introduction, wyd. 2, Oxford - Malden.

Morgan A., 2017, Solving the Puzzle of Aesthetic Assertion, „Southwest Philosophy Review" 33, nr 1, s. 95-103, https://doi.org/10.5840/swphilreview201733110.

Norrick N., 2001, On the Conversational Performance of Narrative Jokes: Toward an Account of Timing, „Humor” 14, s. 255-274, https://doi.org/10.1515/humr.2001.003.

Olsen S.H., Pettersson A. (red.), 2005, From Text to Literature. New Analytic and Pragmatic Approaches, London, https://doi.org/10.1057/9780230524170.

Petrey S., 1990, Speech Acts and Literary Theory, London.

Pilkington A., 2010, Literary Pragmatics, [w:] L. Cummings (red.), The Pragmatics Encyclopedia, Abingdon, s. 251-253.

PIsAR KOWA K., 1994, Z pragmatycznej stylistyki, semantyki i historii języka. Wybór zagadnień, Kraków.

Ротоска M.A., 2007, Estetyka kontra sztuka. Kompromitacja założeń estetycznych $w$ konfrontacji ze sztuka nowoczesną, Warszawa.

PRATt M.L., 1977, Toward a Speech Act Theory of Literary Discourse, Bloomigton - London.

SELL R.D. (red.), 1991, Literary Pragmatics, London.

SiL'MAN T., 1977, Zametki o lirike, Leningrad.

SŁAWiński J., 1974, Dzieło. Język. Tradycja, Warszawa.

SтĘPNIK K., 1988, Filozofia metafory, Lublin.

Traugott E.C., 1973, Generative Semantics and the Concept of Literary Discourse, „Journal of Literary Semantics" 2, s. 5-22.

Vendler Z., 1976, Illocutionary Suicide, [w:] A.F. MacKay, D.D. Merrill (red.), Issues in the Philosophy of Language. Proceedings of the 1972 Oberlin Colloquium in Philosophy, New Haven, s. 135-145.

WANAT T., 2006, Rola efektu pierwszeństwa w publikacjach prasowych, „Ruch Prawniczy, Ekonomiczny i Socjologiczny" nr 1, s. 205-214.

Zeller C., 2010, Ästhetik des Authentischen: Literatur und Kunst um 1970, Berlin - Boston, https://doi.org/10.1515/9783110227215.

\section{Aesthetic Acts of Speech as a Subject of Pragmalinguistics: Status, Functions, Forms. Part 1 Abstract}

In the paper, the status and features of aesthetic speech acts are discussed. They are a research phenomenon at the junction of two disciplines: pragmatics and stylistics. The authors treat aesthetic speech acts as these kinds of speech acts that are produced by the sender with an intention to make the receiver have an aesthetic experience, however, they are not limited solely to the field of literature. No performative verbs can be ascribed to them, therefore they may be categorized as indirect stimulating acts. Moreover, the aesthetic function performed by such speech acts is frequently accompanied by other linguistic functions. 